\title{
Alpha-2-Macroglobulin Inhibits the Anticoagulant Action of Activated Protein C in Cord and Adult Plasma
}

\author{
Gerhard Cvirn Siegfried Gallistl Wolfgang Muntean \\ Ludwig Boltzmann Research Institute for Pediatric Hemostasis and Thrombosis, and
}

Department of Pediatrics, University of Graz, Austria

\section{Key Words}

Activated protein C .

Alpha-2-macroglobulin - Thrombin

potential $\cdot$ Prothrombin activation manner when a2-M levels were successively elevated, reflected in increased thrombin potential (TP), and enhanced at low a2-M levels, reflected in decreased TP.

Copyright $@ 2001$ S. Karger AG, Basel

\begin{abstract}
Healthy newborns have a very low risk of thrombosis. It has been suggested that this is partly due to the anticoagulant effect of alpha-2-macroglobulin (a2-M). This broadspectrum protease binding glycoprotein is physiologically elevated in newborns over adult values and has been shown to complex generated alpha-thrombin. In our present study, we point out that a2-M also acts as a procoagulant by inhibiting activated protein C (APC). In all experiments performed in cord and adult plasma the anticoagulant action of APC was diminished in a dose-dependent
\end{abstract}

\begin{tabular}{ll}
\hline KARGER & ( ) 2001 S. Karger AG, Basel \\
Fax +4161306 1234-0147/01/0311-0001\$17.50/0 \\
$\begin{array}{l}\text { E-Mail karger@karger.ch } \\
\text { www.karger.com }\end{array}$ & $\begin{array}{l}\text { Accessible online at: } \\
\text { www.karger.com/journals/hae }\end{array}$
\end{tabular}

\section{Introduction}

The risk for thromboembolic complications is considerably less for newborns and children than for adults for any given insult, due to lower plasma concentrations of vitamin K-dependent coagulation factors, i.e. prothrombin, and contact factors $[1,2]$. The capacity of cord plasma to generate thrombin is decreased to $30-50 \%$ of adult values [3]. In addition, alpha-2-macroglobulin (a2M) has been suggested as a major anticoagulant protein in infancy and has been demon-

\footnotetext{
Mag. Gerhard Cvirn

Universitätsklinik für Kinder- und Jugendheilkunde, Gerinnungslabor

Auenbruggerplatz 30, A-8036 Graz (Austria)

Tel. +43316385 4031, Fax +433163854024

E-Mail gerhard.cvirn@klinikum-graz.at
} 
strated to complex up to $49 \%$ of generated alpha-thrombin in cord plasma $[4,5]$. On the other hand, a2-M has been shown to bind activated protein C (APC) [6], one of the most important anticoagulant proteins. In addition, increased complex formation between a2-M and APC has been demonstrated to be associated with an unfavorable outcome in patients suffering from disseminated intravasal coagulation (DIC) [7], suggesting that a2-M might diminish the anticoagulant action of APC. Previously, we have demonstrated a dose-dependent anticoagulant effect of APC in cord and adult plasma using the determination of thrombin generation (thrombin potential, TP) [8]. The TP has been shown to be a reliable parameter to assess the combined effects of all the factors that may influence thrombin generation in a given sample [9-13].

We investigated the effect of different concentrations of a2-M on the anticoagulant action of APC in both cord and adult plasma since levels of a2-M and APC during delivery are elevated over adult values [14] by using the determination of the TP. In addition, since the TP does not exactly reflect the amount of prothrombin activated, we determined the generation of prothrombin fragments $1+2(F 1+2)$ in the presence of different concentrations of a2-M.

\section{Materials and Methods}

\section{Reagents}

Buffer A contains $0.05 M$ Tris- $\mathrm{HCl}$ at $\mathrm{pH} 7.4$, $0.1 M \mathrm{NaCl}$ and $0.5 \mathrm{M}$ bovine serum albumin. Buffer $\mathrm{B}$ is analogous to buffer A but contains in addition $20 \mathrm{~m} M$ EDTA. a2-M concentrate from human plasma was purchased from Sigma, Vienna, Austria. A stock solution was prepared by dissolving $10 \mathrm{mg}$ of the lyophilized glycoprotein in $500 \mu \mathrm{l}$ of distilled water, dialysis against buffer $\mathrm{A}$ for $3 \mathrm{~h}$ at $4{ }^{\circ} \mathrm{C}$, aliquots of $100 \mu \mathrm{l}$ were stored at $-70^{\circ} \mathrm{C}$. APC from human plasma was obtained from ICN Biomedicals $\mathrm{GmbH}$, Esch- wege, Germany. A stock solution was prepared by dissolving $10 \mu \mathrm{g}$ of the lyophilized protein in $370 \mu \mathrm{l}$ of distilled water, dialysis against buffer $\mathrm{A}$ for $3 \mathrm{~h}$ at $4{ }^{\circ} \mathrm{C}$, aliquots of $30 \mu \mathrm{l}$ were stored at $-70^{\circ} \mathrm{C}$. Proteinase A, an enzyme from the venom of the Mexican west-coast rattlesnake (Crotalus basiliscus), was purchased from Pentapharm Ltd, Basel, Switzerland. To $0.175 \mathrm{mg}$ of the lyophilized protein, $400 \mu \mathrm{l}$ of distilled water was added and stored at $4{ }^{\circ} \mathrm{C}$. Unitest ${ }^{\mathrm{TM}}$ Assay for a2-M determination in human plasma was obtained from CoaChrom Diagnostics, Vienna, Austria. As a trigger for the extrinsic coagulation pathway, we used Thromborel S from Behring Diagnostics $\mathrm{GmbH}$, Marburg, Germany, containing human placental thromboplastin and calcium chloride. The fibrin polymerization inhibitor H-Gly-Pro-Arg-Pro-OH (GPRP, Pefabloc FG) was purchased from Pentapharm Ltd. The chromogenic substrate used for thrombin determination was H- $D$ Phe-Pip-Arg-pNA.2HCl (S-2238) from CoaChrom Diagnostics. Test kit F1+2 Micro for determination of prothrombin $\mathrm{F} 1+2$ generation was obtained from Behring Diagnostics $\mathrm{GmbH}$. Stopping solution for F1+2 determination consisted of Trasylol:EDTA:Nacitrate $=8: 1: 1$ and $110 \mu M$ PPACK ( $D$-Phe-Pro-Arg chloromethyl-ketone) from Sigma. Trasylol from Bayer, Vienna, Austria contained aprotinin, a protease inhibitor.

\section{Collection and Preparation of Plasma}

Cord blood was obtained immediately following the delivery of 12 full-term infants (38-42 weeks' gestational age). It was collected into $0.1 M$ citrate using a two-syringe technique, centrifuged at room temperature for $15 \mathrm{~min}$ at $2,800 \mathrm{~g}$, pooled and stored at $-70^{\circ} \mathrm{C}$ in propylene tubes until assayed. Clotting factors, AT, protein $\mathrm{C}$, protein $\mathrm{S}$, and a2-M in the pooled cord plasma were in the normal range for neonates. In the same way, plasma from 10 healthy adults was collected, prepared and checked.

\section{Preparation of Plasma with Different a2-M \\ Concentration}

The a2-M activity of the pooled neonatal or adult plasma was decreased by supplementation of proteinase A, a metalloenzyme that forms a complex with a2-M at a molar ratio of $1: 1[15,16]$. To $1 \mathrm{ml}$ of plasma, different amounts $(0-20 \mu \mathrm{l})$ of proteinase A were added, resulting in a2-M activities from 1.8 to $3.6 \mu M$ for cord plasma and from 1.1 to $2.0 \mu M$ for adult plasma, respectively. To increase the a2-M concentration, to $1 \mathrm{ml}$ of plasma, different amounts (0$80 \mu \mathrm{l})$ of purified a2-M concentrate were added, resulting in a2-M concentrations from 3.6 to $5.9 \mu M$ in 
cord plasma and from 2.0 to $4.6 \mu M$ in adult plasma, respectively.

\section{Determination of the a2-M Concentration}

Determination of the a2-M concentration of pooled cord and adult plasma was performed using the standard test kit Unitest ${ }^{\mathrm{TM}}$ Assay for a2-M determination in human plasma from CoaChrom Diagnostics.

\section{Determination of the $\mathrm{PC}$ Content}

Determination of the $\mathrm{PC}$ content of pooled plasma was performed by means of a standard coagulation method using protein $\mathrm{C}$-deficient plasma on a Behring Coagulation Timer from Behring Diagnostics $\mathrm{GmbH}$.

\section{Activation of Plasma}

$200 \mu \mathrm{l}$ of plasma with different a2-M concentrations was incubated with $10 \mu \mathrm{l}$ of buffer A (containing different amounts of APC) for $1 \mathrm{~min}$ at $37^{\circ} \mathrm{C}$. After subsequent incubation with $20 \mu \mathrm{l}$ buffer A containing $1.0 \mathrm{mg} / \mathrm{ml} \mathrm{H}$-Gly-Pro-Arg-Pro-OH (GPRP, Pefabloc FG) for $1 \mathrm{~min}$ at $37^{\circ} \mathrm{C}$ to inhibit fibrin polymerization, the plasma samples were activated by addition of $200 \mu \mathrm{l}$ Thromborel $\mathrm{S}$ and thrombin generation was recorded. Clotting times were determined in the absence of Pefabloc FG on a Behring Fibrin Timer from Behring Diagnostics $\mathrm{GmbH}$.

\section{Determination of Thrombin Generation}

We used a subsampling method derived from a recently described technique $[10,13]$. Plasmas were prepared and activated as described above. At timed intervals, $10-\mu 1$ aliquots were withdrawn from the activated plasma and subsampled into $490 \mu \mathrm{l}$ buffer B containing $225 \mu \mathrm{M} \mathrm{S}-2238$. The reagents were prewarmed to $37^{\circ} \mathrm{C}$. Amidolysis of S-2238 was stopped after 6 min by addition of $250 \mu 150 \%$ acetic acid. The amount of thrombin generated was quantitated by measuring the absorbance by double wavelength (405$690 \mathrm{~nm}$ ) in the Anthos microplate reader 2001, from Anthos Labtec Instruments GmbH, Salzburg, Austria. The total amidolytic activity measured is caused by the simultaneous activity of free thrombin and a2-M/ thrombin complex [9]. The amount of free thrombin was determined by two different methods: (A) At timed intervals, aliquots of the extrinsically activated plasma were subsampled into buffer B containing heparin $(20 \mathrm{U} / \mathrm{ml})$ and AT $(3.4 \mathrm{U} / \mathrm{ml})$ to rapidly and completely inactivate free thrombin in the sample. The residual amidolytic activity was then determined as described above for the total amidolytic activity. The amidolytic activity of the a2-M/thrombin complex was subtracted from the total amidolytic activity [3].
(B) Free thrombin generation curves were calculated by mathematical treatment of total amidolytic activity curves using a method developed by Hemker et al. [10].

\section{Determination of Prothrombin F1+2}

Plasmas were prepared and activated as described above. At timed intervals, $5-\mu 1$ aliquots were withdrawn from the plasma and subsampled into $495 \mu \mathrm{l}$ stopping solution. After subsequent 1:10 dilution in stopping solution, the amount of F1+2 generated was quantitated by using a standard immunoenzymatic test kit.

\section{Statistical Analysis}

The results shown are expressed as means $(n=3)$. Data were statistically analyzed for significance using the Kruskal-Wallis nonparametric analysis of variance taking $\mathrm{p}<0.05$ to indicate a significant difference. Pearson's correlation was used to assess the relation between different a2-M levels and the respective thrombin potentials, end levels of the prothrombin generation curves, and clotting times.

\section{Results}

To determine free thrombin generation curves from total amidolytic activity curves, we used two different methods as described in Material and Methods. Both methods resulted in the same free amidolytic activity curves. Experiments were done in cord plasma over a concentration range of 1.8-5.9 $\mu M$ a2-M and in adult plasma over a concentration range of 1.1-4.6 $\mu M$ a2-M. Protein $\mathrm{C}$ concentration was $90 \%$ in pooled adult and $42 \%$ in pooled cord plasma. All experiments were done in triplicate; the average is shown in all figures. SEM were not shown for clarity of graph reading but represented less than $10 \%$ of the mean. The capacity of normal cord plasma to generate free thrombin was decreased to about $50 \%$ as compared to adult plasma. 
Fig. 1. a Free thrombin generation in cord plasma containing 2.0, 3.6 or $4.3 \mu \mathrm{M}$ a2-M in the absence of APC $(\boldsymbol{\square}$, TP $=291 \mathrm{n} M \cdot \min )$. Effects of supplementation of $21 \mathrm{n} M$ APC to plasma with different a2-M concentrations $(\boldsymbol{\nabla}, 2.0 \mu M, \mathrm{TP}=$ $150 \mathrm{n} M \cdot \min ; \boldsymbol{\Lambda}, 3.6 \mu M, \mathrm{TP}=236$ $\mathrm{n} M \cdot \min ; \bullet, 4.3 \mu M, \mathrm{TP}=291$ $\mathrm{n} M \cdot \min )$ on free thrombin generation. $\mathbf{b}$ Reduction of the TP by addition of $21 \mathrm{n} M(\mathbf{\square})$ or $42 \mathrm{n} M(\mathbf{O}$ APC to plasma containing 1.8-5.9 $\mu M$ a2-M related to corresponding plasma in the absence of APC.
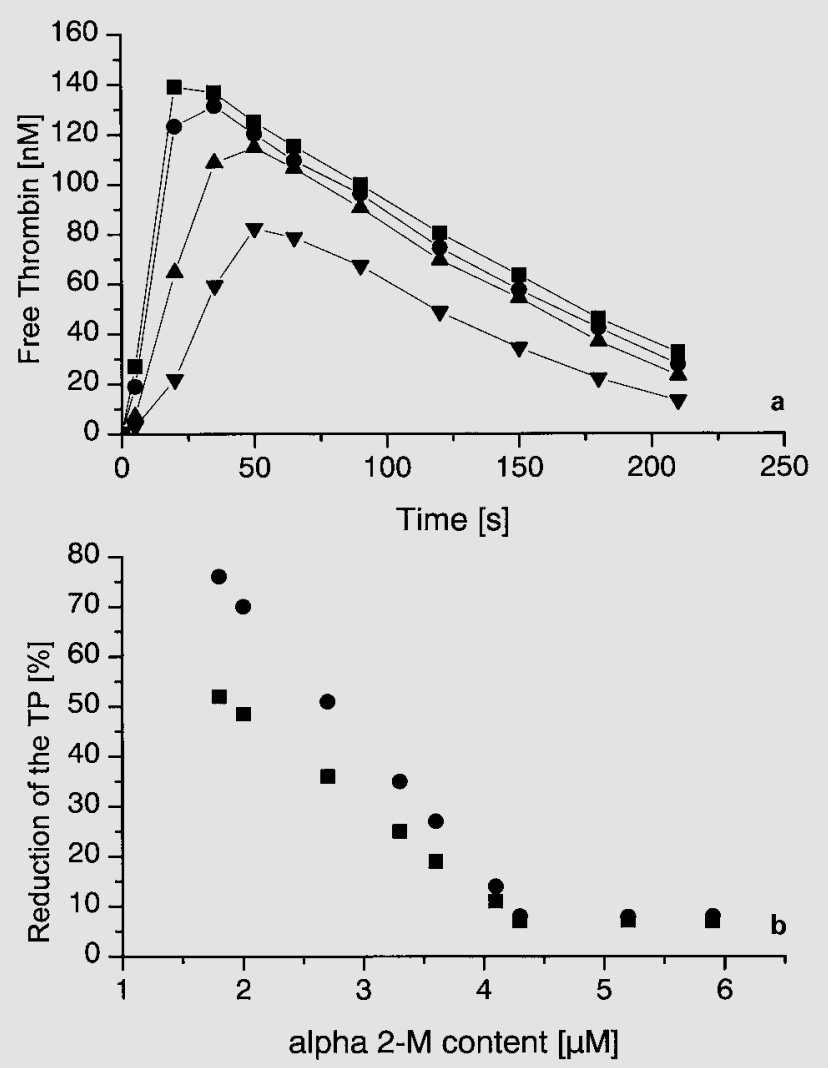

Effect of APC Administration to Plasma with Different a2-M Content on Thrombin Generation

In the absence of APC, the same amounts of free thrombin were generated in cord plasma containing different amounts of a2-M (fig. 1). Reduction of the TP due to addition of $21 \mathrm{n} M$ APC depended on the amount of $\mathrm{a} 2-\mathrm{M}$ present in the cord plasma sample $(\mathrm{p}<$ 0.05 ; fig. 1). Essentially the same results were obtained in adult plasma (fig. 2).
Effect of APC Administration to Plasma with Different a2-M Content on

Prothrombin Activation

In the absence of APC, the same amounts of $\mathrm{F} 1+2$ were generated in cord plasma containing different amounts of a2-M (fig. 3). Suppression of prothrombin activation due to addition of $21 \mathrm{n} M$ APC depended on the a2-M content of the cord plasma sample ( $\mathrm{p}<$ 0.05 ; fig. 3). Essentially the same results were obtained in adult plasma (fig. 4). 
Fig. 2. a Free thrombin generation in adult plasma containing 1.4, 2.0 or $3.2 \mu M$ a2-M in the absence of APC $(\boldsymbol{\square}, \mathrm{TP}=627 \mathrm{n} M \cdot \min )$. Effects of supplementation of $42 \mathrm{n} M$ APC to plasma with different a2-M concentrations $(\boldsymbol{\nabla}, 1.4 \mu M, \mathrm{TP}=$ $277 \mathrm{n} M \cdot \min ; \boldsymbol{\Delta}, 2.0 \mu M, \mathrm{TP}=428$ $\mathrm{n} M \cdot \min ; \bullet, 3.2 \mu M, \mathrm{TP}=627$ $\mathrm{n} M \cdot \min )$ on free thrombin generation. $\mathbf{b}$ Reduction of the TP by addition of $21 \mathrm{n} M(\mathbf{\square})$ or $42 \mathrm{n} M($ APC to plasma containing 1.1-4.6 $\mu M$ a2-M related to corresponding plasma in the absence of APC.
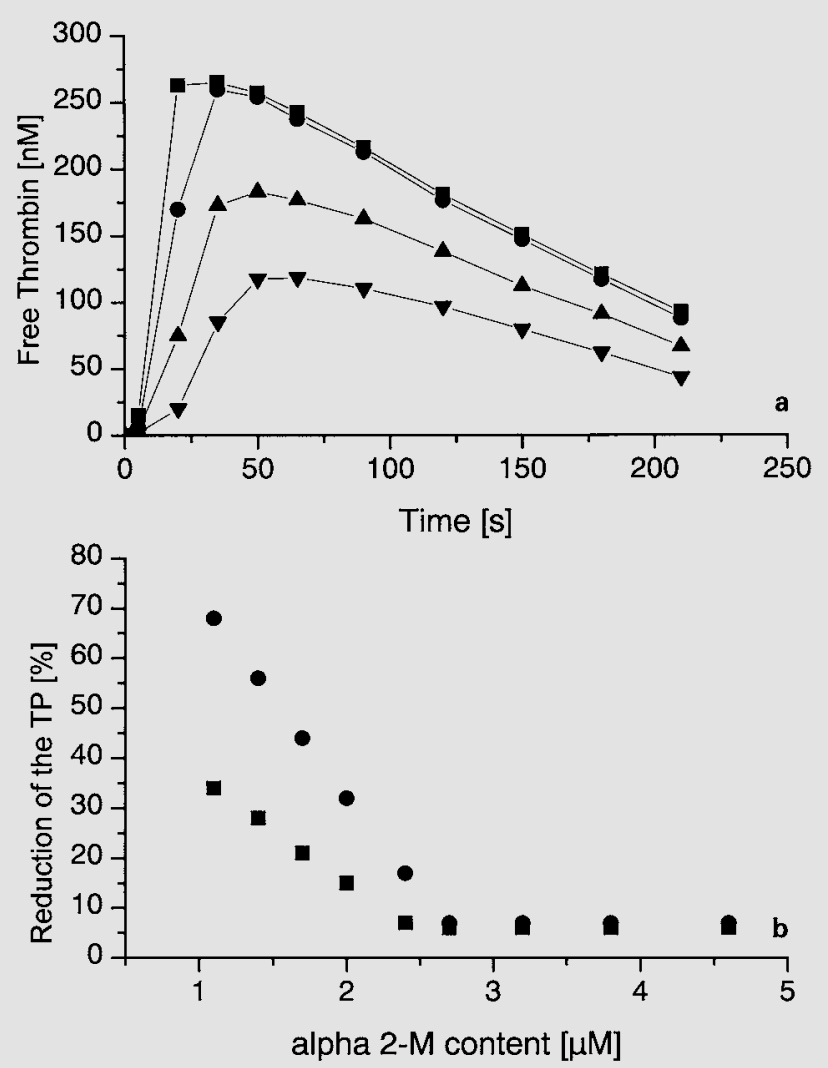

\section{Effect of APC Administration to Plasma} with Different a2-M Content on Clotting

Time

Prolongation of the clotting time due to addition of 21 or $42 \mathrm{nM}$ APC (final) depended on the amount of a2-M present in the given cord or adult plasma sample $(\mathrm{p}<0.01$; fig. 5).

Effect of a High-Dose Application of APC on TP in Plasma with Physiologic and Elevated a2-M Level

Addition of $56 \mathrm{n} M$ APC (final) to cord plasma containing 3.6 $\mu M$ a2-M (physiologic concentration in cord plasma) resulted in a significant decrease of thrombin generation compared to plasma with physiologic concentration of a2-M in the absence of APC. The calculated area under the thrombin generation curve decreased from 291 to $157 \mathrm{n} M$. $\min (\mathrm{p}<0.05)$, shown in figure 6a. Administration of the same amount of APC to cord plasma containing 5.9 $\mu \mathrm{M}$ a2-M had no significant effect on thrombin generation compared to plasma with the same a2-M content in the absence of APC, shown in figure 6b. Comparable results were obtained in adult plasma. Addition of $81 \mathrm{n} M$ APC (final) to 
Fig. 3. a Prothrombin F1+2 activation in cord plasma containing 2.7 or $4.1 \mu M$ a2-M in the absence of $\mathrm{APC}(\boldsymbol{\square}, 0.6 \mu M \mathrm{~F} 1+2$ end level $)$. Effects of supplementation of 21 $\mathrm{n} M$ APC to plasma with $2.7 \mu M$ $(\boldsymbol{\Lambda}, 0.38 \mu M \mathrm{~F} 1+2$ end level $)$ or 4.1 $\mu M(\bullet, 0.54 \mu M$ F $1+2$ end levels $)$ a2-M on F1+2 generation. b Reduction of $\mathrm{F} 1+2$ generation by addition of $21 \mathrm{n} M(\mathbf{\square})$ or $42 \mathrm{n} M(\mathbf{0}$ APC to plasma containing 1.8-5.9 $\mu M$ a2-M related to corresponding plasma in the absence of APC.
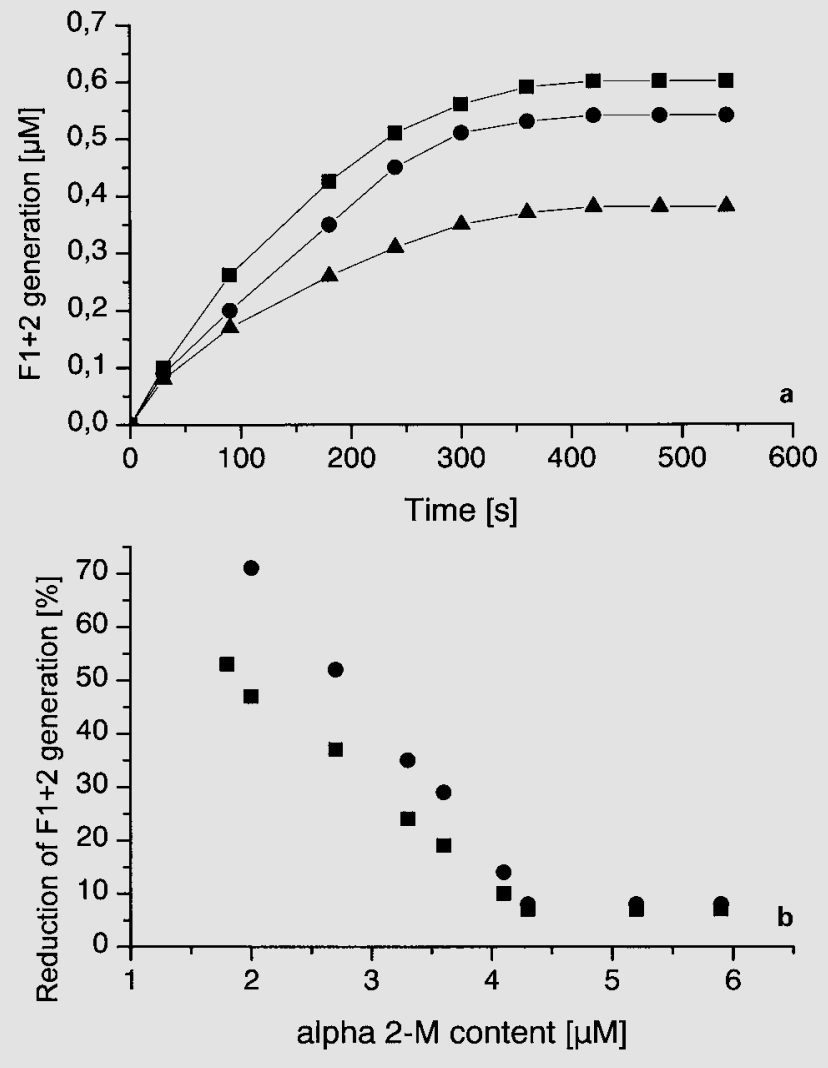

plasma containing $2.0 \mu \mathrm{M}$ a2-M (physiologic concentration in adult plasma) resulted in a significant decrease of thrombin generation compared to plasma with physiologic a2-M concentration in the absence of APC. The calculated area under the thrombin generation curve decreased from 627 to $241 \mathrm{n} M \cdot \min$ $(p<0.05)$, shown in figure 7a. Addition of the same amount of APC to adult plasma at elevated a2-M level $(3.8 \mu M)$ did not significantly decrease thrombin generation compared to plasma with the same a2-M content in the absence of APC, shown in figure $7 \mathrm{~b}$.

\section{Discussion}

APC exhibits its anticoagulant activity by proteolytic cleavage of activated factors $\mathrm{V}$ and VIII $[17,18]$ and thus prevents feedback activation of thrombin [19]. The effect of APC on thrombin generation in adult plasma of normal and APC-resistent individuals to detect a potential prothrombotic status has recently been reported [20]. Additionally, it has been shown by Hoogendoorn et al. [6] that a2-M binds and inhibits APC. They demonstrated a time-dependent inhibition of APC by a2-M using an activated partial thromboplastin 
Fig. 4. a F1+2 activation in adult plasma containing 1.4 or $2.4 \mu M$ a2-M without APC administration (ם, $1.2 \mu M$ F1+2 end level). Effects of supplementation of $42 \mathrm{n} M$ APC to plasma with $1.4 \mu M(\mathbf{\Delta}, 0.53$ $\mu M \mathrm{~F} 1+2$ end level $)$ or $2.4 \mu M(\bullet$, $1.0 \mathrm{~m} M \mathrm{~F} 1+2$ end level) a2-M on $\mathrm{F} 1+2$ generation. b Reduction of $\mathrm{F} 1+2$ generation by addition of 21 $\mathrm{n} M(\square)$ or $42 \mathrm{n} M(\bullet)$ APC plasma containing 1.1-4.6 $\mu \mathrm{M}$ a2-M related to corresponding plasma in the absence of APC.
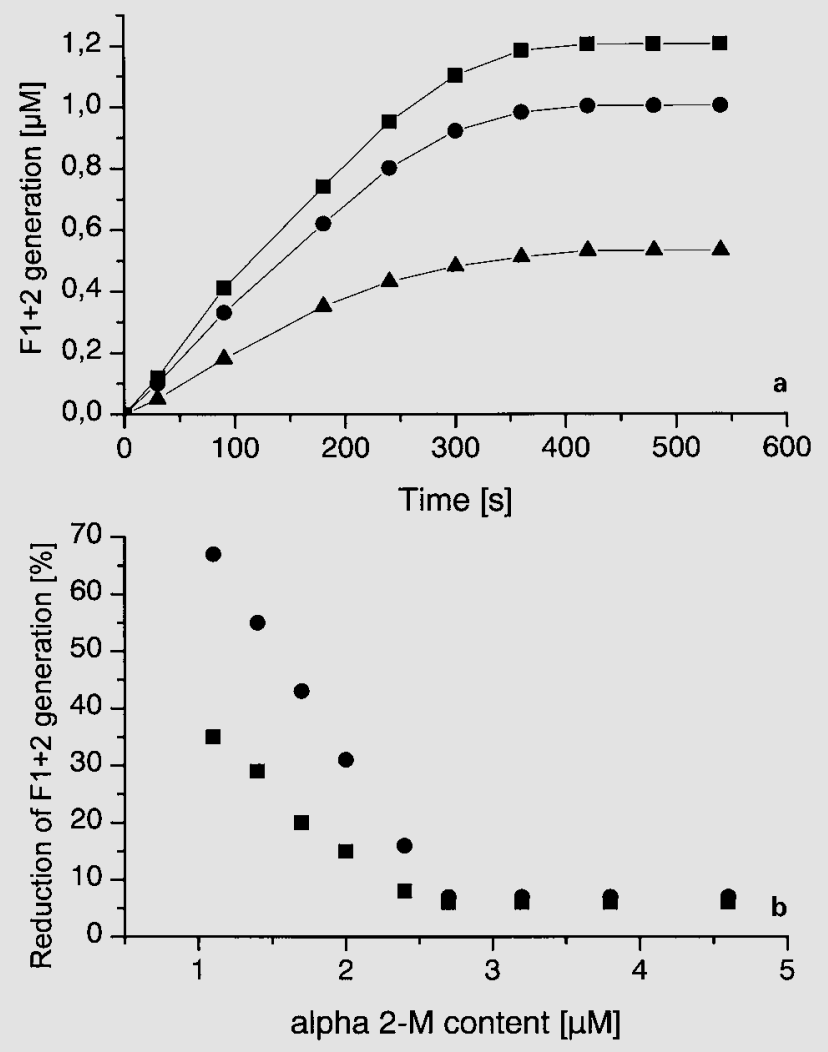

time-based APC assay. Our data are in good agreement with these findings. However, it has been suggested that determination of clotting time does not necessarily reflect the coagulant potency of plasma since only a small amount of thrombin has been generated when the fibrin clot occurs [9]. Consequently, features of the thrombin-generation process that take place after clotting has occurred are not reflected in the clotting time. Therefore, determination of free thrombin generation has been suggested to be a more reliable parameter to assess the combined action of procoagulant and anticoagulant factors in plasma [11].
We have described previously a dose-dependent anticoagulant effect of APC using the determination of thrombin generation after intrinsic activation [8]. In cord and adult plasma, Protac [21]-induced APC reduced the amount and prolonged the lag times until the onset of free thrombin generation. These results were reproduced in the present study after addition of already activated protein $\mathrm{C}$. Plasmas were activated by supplementation of thromboplastin (Thromborel S) and calcium ions. Complex formation between a2-M and APC effectively only occurs in the presence of divalent metal ions [22]. After addi- 
Fig. 5. a Prolongation of clotting time by addition of $21 \mathrm{n} M(\boldsymbol{\square})$ or $42 \mathrm{n} M(\bullet)$ APC to cord plasma containing 1.8-5.9 $\mu \mathrm{M}$ a2-M related to corresponding plasma in the absence of APC. $\mathbf{b}$ Prolongation of clotting time by addition of $21 \mathrm{nM}$ (口) or $42 \mathrm{n} M(\bullet)$ APC to adult plasma containing 1.1-4.6 $\mu \mathrm{M}$ a2$\mathrm{M}$ related to corresponding plasma in the absence of APC.

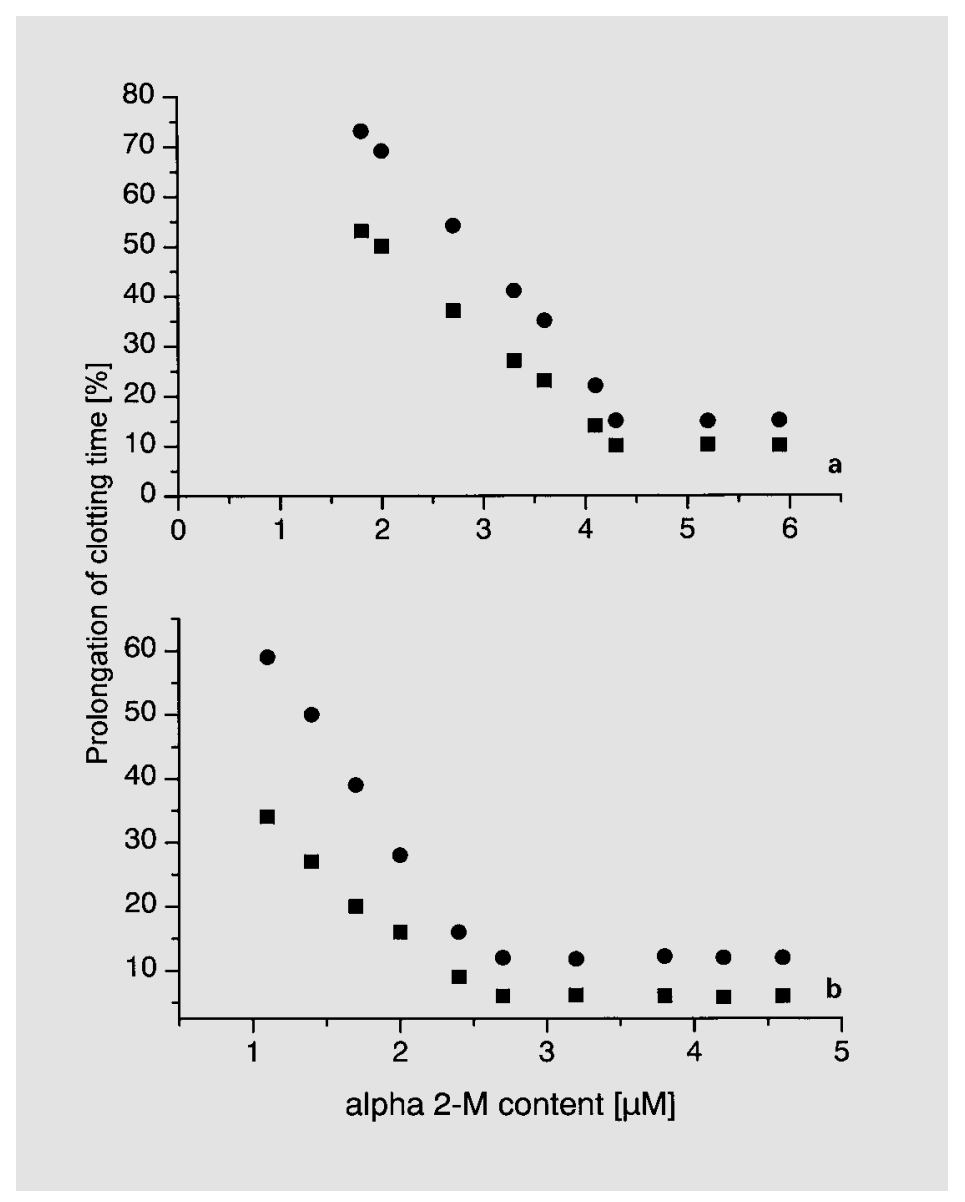

tion of a2-M, the anticoagulant effect of APC was diminished. In addition, the anticoagulant effect of APC was enhanced when a2-M was inhibited by proteinase $\mathrm{A}[15,16]$ in both cord and adult plasma. We found no difference in the inhibitory effect of a2-M on APC anticoagulant function in cord and adult plasma. In accordance with the effect on free thrombin generation, a2-M diminished the inhibiting effect of APC on prothrombinase activity assessed by determination of prothrombin $\mathrm{F} 1+2$ in both cord and adult plasma.

The observation that a2-M diminishes the effect of APC on feedback activation of thrombin is intriguing since it has been shown that a2-M accounts for a large amount of thrombin inhibition, especially in cord plasma [4]. Studies dealing with thrombin inhibition by a2-M determined thrombin/a2-M complex formation after a certain period of plasma incubation and did not assess the time course of thrombin generation and inhibition $[23,24]$. The action between a2-M and thrombin might not be fast enough [25] to prevent thrombin from feedback activation of factors $\mathrm{V}$ and VIII, thereby inducing prothrombinase formation. Thus, the same free thrombin generation curves result for plasma containing 
Fig. 6. a Effect of supplementation of $0 \mathrm{n} M(\mathbf{\square})$ or $56 \mathrm{n} M(\mathbf{0})$ APC to cord plasma containing $3.6 \mu M$ a2-M on generation of free thrombin. $\mathbf{b}$ Effect of supplementation of $0 \mathrm{n} M(\square)$ or $56 \mathrm{n} M(\mathbf{O})$ APC to cord plasma containing $5.9 \mu \mathrm{M}$ a2$\mathrm{M}$ on free thrombin generation.

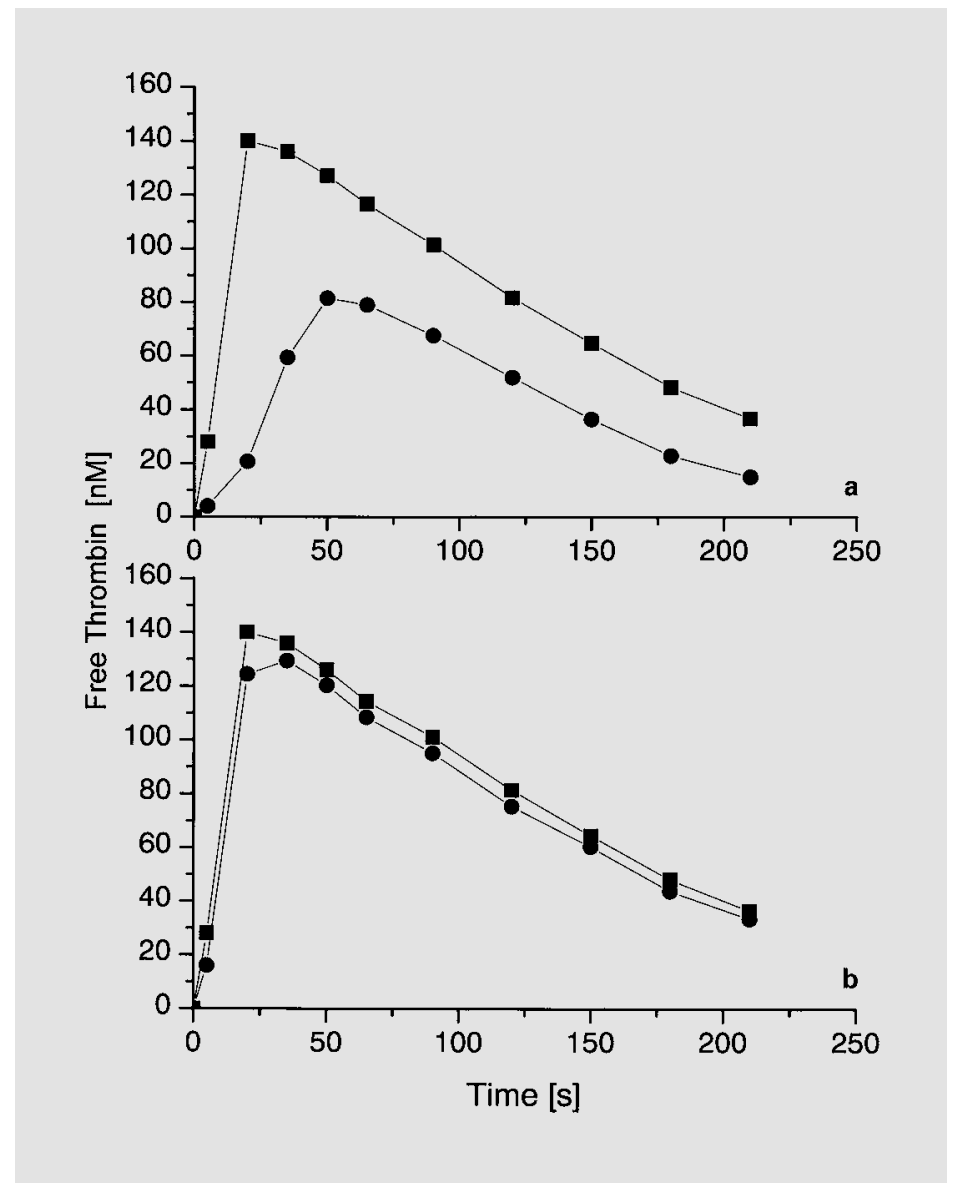

different amounts of a2-M at physiologic antithrombin levels. Proteinases are trapped within the 'bait region' of a2-M resulting in conformational change $[26,27]$. Thus, although a2-M inactivates procoagulant proteins such as factor $\mathrm{Xa}$ and thrombin, inhibition of the anticoagulant factor APC counteracts its anticoagulant effect.

Beside a2-M, protein $\mathrm{C}$ inhibitor and alpha-1-antitrypsin (a1-A) contribute to APC inactivation [28, 29]. Scully et al. [7] investigated the activation of protein $\mathrm{C}$ and its distribution between its inhibitors in patients with DIC and suggested that a2-M and a1-A ap- peared to assume greater roles in inhibition of APC in 2 fatal cases. a2-M increases during the initial phase of sepsis and subsequently decreases due to multiple complex formation with proteinases. Availability of APC seems to be predictive for the outcome of critically sick patients and application of APC results in favorable outcome [30, 31].

Although laboratory experiments obviously do not allow definite conclusions for various clinical situations, our data suggest that a2-M might modulate the anticoagulant property of APC in both cord and adult plasma. 
Fig. 7. a Effect of supplementation of $0 \mathrm{n} M(\mathbf{\square})$ or $81 \mathrm{n} M(\bullet)$ APC to adult plasma containing $2.0 \mu \mathrm{M}$ a2-M on generation of free thrombin. $\mathbf{b}$ Effect of supplementation of $0 \mathrm{n} M(\square)$ or $81 \mathrm{n} M(\bullet)$ APC to adult plasma containing $3.8 \mu \mathrm{M}$ $\mathrm{a} 2-\mathrm{M}$ on free thrombin generation.

\section{References}

1 Andrew M, Paes B, Milner R, Johnston M, Mitchell L, Tollefsen DM, Powers P: Development of the human coagulation system in the fullterm infant. Blood 1987;70:165170.

2 Andrew M, Vegh P, Johnston M, Bowker J, Ofosu F, Mitchell L: Maturation of the hemostatic system during childhood. Blood 1992;8: 1998-2005.

3 Andrew M, Schmidt B, Mitchell L, Paes B, Ofoso F: Thrombin generation in newborn plasma is critically dependent on the concentration of prothrombin. Thromb Haemost 1990;63:27-30.

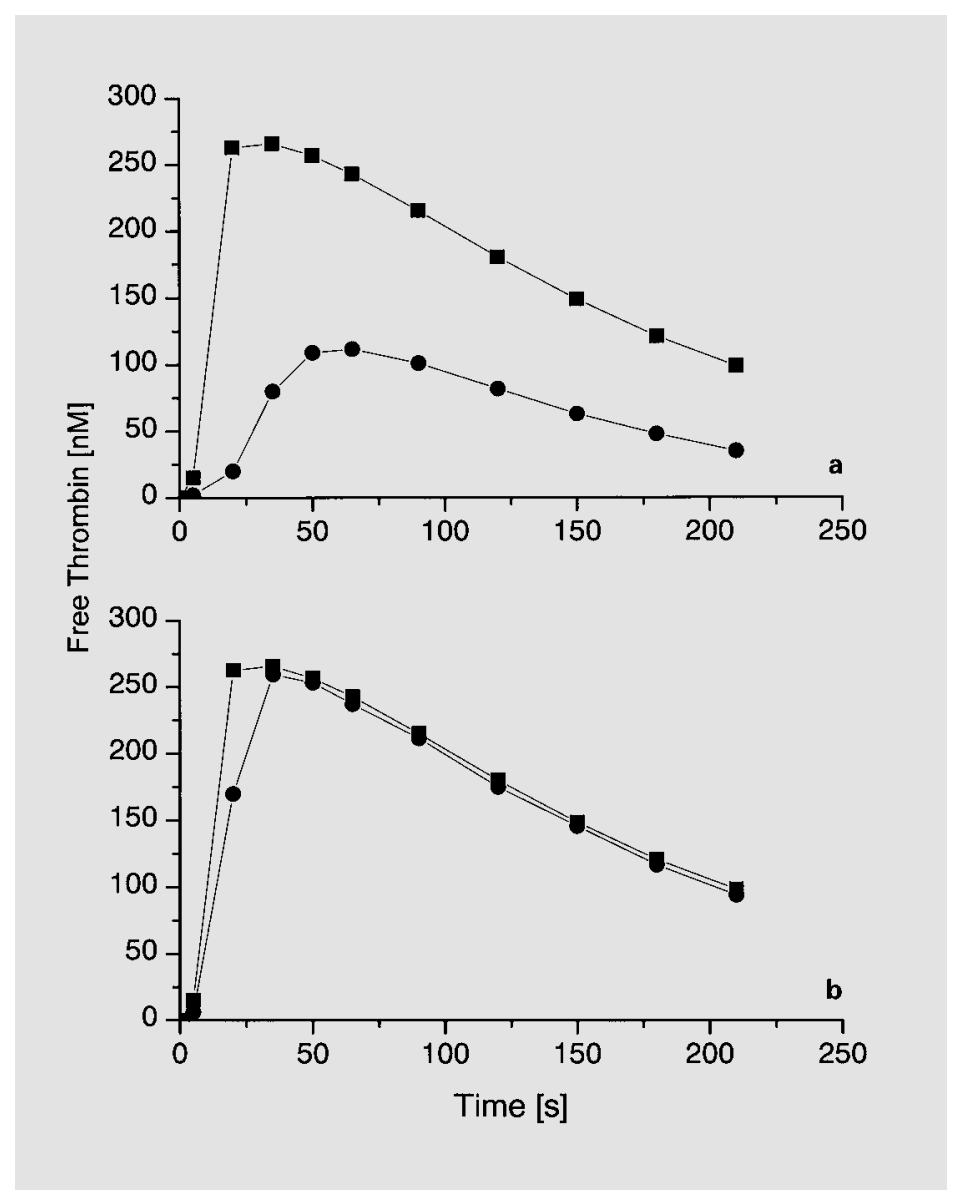

4 Ling X, Delorme M, Berry L, Ofosu F, Mitchell L, Paes B, Andrew M: Alpha-2-macroglobulin remains as important as antithrombin III for thrombin regulation in cord plasma in the presence of endothelial cell surfaces. Pediatr Res 1995;37:373378.

5 Andrew M, Mitchell L, Vegh P, Ofosu F: Thrombin regulation in children differs from adults in the absence and presence of heparin. Thromb Haemost 1994:72:836842.
6 Hoogendoorn $\mathrm{H}$, Toh $\mathrm{CH}$, Nesheim ME, Giles AR: Alpha-2-macroglobulin binds and inhibits activated protein C. Blood 1991;78:22832290.

7 Scully MF, Toh CH, Hoogendoorn $\mathrm{H}$, Manuel RP, Nesheim ME, Solymoss S, Giles AR: Activation of protein $\mathrm{C}$ and its distribution between its inhibitors protein $\mathrm{C}$ inhibitor, alpha-1-antitrypsin and alpha-2macroglobulin, in patients with disseminated intravascular coagulation. Thromb Haemost 1993;69: 448-453. 
8 Cvirn G, Gallistl S, Muntean W: Effects of antithrombin and protein $\mathrm{C}$ on thrombin generation in newborn and adult plasma. Thromb Res 1999;93:183-190.

9 Hemker HC, Willems GM, Beguin $\mathrm{S}$ : A computer-assisted method to obtain the prothrombin activation velocity in whole plasma independent of thrombin decay processes. Thromb Haemost 1986;56:9-17.

10 Hemker HC, Wielders S, Kessels H, Beguin S: Continuous registration of thrombin generation in plasma, its use for the determination of the thrombin potential. Thromb Haemost 1993;70:617-624.

11 Hemker HC, Beguin S: Thrombin generation in plasma: Its assessment via the endogenous thrombin potential. Thromb Hemost 1995;74:134138.

12 Gallistl S, Muntean W, Leis HJ: Effects of heparin and hirudin on thrombin generation and platelet aggregation after intrinsic activation of platelet-rich plasma. Thromb Haemost 1995;74:1163-1168.

13 Wielders S, Mukherjee M, Michiels J, Rijkers DTS, Cambus JP, Knebel RWC, Kakkar V, Hemker HC: The routine determination of the endogenous thrombin potential, first results in different forms of hyper- and hypocoagulability. Thromb Haemost 1997;77:629-636.

14 Petaja J, Fernandez JA, Fellman V, Griffin JH: Upregulation of the antithrombotic protein $\mathrm{C}$ pathway at birth. Pediatr Hematol Oncol 1998; 15:489-499.

15 Svoboda P, Meier J, Freyvogel TA: Purification and characterization of three $\alpha_{2}$-antiplasmin and $\alpha_{2}$-macroglobulin inactivating enzymes from the venom of the Mexican westcoast rattlesnake (Crotalus basiliscus). Toxicon 1995;33:1331-1346.
16 Rijkers DTS, Wielders SJH, Beguin $\mathrm{S}$, Hemker HC: Prevention of the influence of fibrin and alpha-2macroglobulin in the continuous measurement of the thrombin potential: Implications for an endpoint determination of the optical density. Thromb Res 1998;89:161-169.

17 Fulcher CA, Gardiner JE, Griffin JH, Zimmermann TS: Proteolytic inactivation of human factor VII procoagulant protein by activated human protein $\mathrm{C}$ and its analogy with factor V. Blood 1984;63:486489.

18 Lu D, Kalafatis M, Mann KG, Long GL: Comparison of activated protein $\mathrm{C}$ /protein S-mediated inactivation of human factor VIII and factor V. Blood 1996;87:4708-4717.

19 Clouse LH, Comp PC: The regulation of hemostasis: The protein $\mathrm{C}$ system. N Engl J Med 1986;314: 1298-1304.

20 Nicolaes GAF, Thomassen MCLGD, Tans G, Rosing J, Hemker HC: Effect of activated protein $\mathrm{C}$ on thrombin generation and on the thrombin potential in plasma of normal and APC-resistant individuals. Blood Coagul Fibrinolysis 1997 . 8:28-38.

21 Kisiel W, Kondo S, Smith KJ, McMullen BA, Smith LF: Characterization of a protein $\mathrm{C}$ activator from Agkistrodon contortrix contortrix venom. J Biol Chem 1987;262: 12607-12613.

22 Heeb MJ, Gruber A, Griffin JH: Identification of divalent metal iondependent inhibition of activated protein $\mathrm{C}$ by alpha-2-macroglobulin and alpha-2-antiplasmin in blood and comparisons to inhibition of factor Xa, thrombin, and plasmin. J Biol Chem 1991;266:17606-17612.

23 Mitchell L, Piovella F, Ofosu F, Andrew M: Alpha-2-macroglobulin may provide protection from thromboembolic events in antithrombin III-deficient children. Blood 1991; 78:2299-2304.
24 Massicote P, Leaker M, Marzinotto V, Adams M, Freedom R, Williams W, Vegh P, Berry L, Shah B, Andrew M: Enhanced thrombin regulation during warfarin therapy in children compared to adults. Thromb Haemost 1998;80:570-574.

25 Jesty J: The kinetics of inhibition of $\alpha$-thrombin in human plasma. J Biol Chem 1986;261:10313-10318.

26 Dangott LJ, Puett D, Cunningham LW: Changes in alpha-2-macroglobulin conformation by reaction with trypsin and methylamine. Ann NY Acad Sci 1983;421:158-159.

27 Steiner JP, Bhattacharya P, Strickland DK: Thrombin-induced conformational changes of human alpha-2-macroglobulin: Evidence for two functional domains. Biochemistry 1985;24:2993-3001.

28 Elisen MG, von dem Borne PA, Bouma BN, Meijers JC: Protein C inhibitor acts as a procoagulant by inhibiting the thrombomodulin-induced activation of protein $\mathrm{C}$ in human plasma. Blood 1998;91:15421547.

29 Heeb MJ, Griffin JH: Physiologic inhibition of human activated protein $\mathrm{C}$ by alpha-1-antitrypsin. J Biol Chem 1988;263:11613-11616.

30 Dreyfus M, Magny JF, Bridey F, Schwarz HP, Planché C, Dehan M, Tchernia G: Treatment of homozygous protein $\mathrm{C}$ deficiency and neonatal purpura fulminans with a purified protein $\mathrm{C}$ concentrate. $\mathrm{N}$ Engl J Med 1991;325:1565-1568.

31 Rivard GE, David M, Farrell C, Schwarz HP: Treatment of purpura fulminans in meningococcemia with protein $\mathrm{C}$ concentrate. $\mathrm{J}$ Pediatr 1995; 126:646-652. 